\title{
Seasonal changes in phytoplankton growth and microzooplankton grazing at an Antarctic coastal site
}

\author{
Imojen Pearce, Andrew T. Davidson*, Simon Wright, Rick van den Enden \\ Australian Government Antarctic Division and Antarctic Climate and Ecosystems Cooperative Research Centre, \\ Channel Highway, Kingston, 7050 Tasmania, Australia
}

\begin{abstract}
Despite being a major pathway for carbon flow in aquatic systems, little is known about annual changes in microzooplankton grazing in Antarctic waters and its top-down control of phytoplankton. We determined changes in the growth and mortality of phytoplankton in near-shore waters off East Antarctica between February and November 2004 using the grazing dilution technique. Results showed large seasonal variation in the microzooplankton grazing rate and top-down control of phytoplankton. In late summer (February to March), microzooplankton consumed around $34 \%$ of primary production and $33 \%$ of the phytoplankton standing stock $\mathrm{d}^{-1}$. As sea ice formed in early April, grazing mortality increased to $762 \%$ of primary production and $72 \%$ of the phytoplankton standing stock $\mathrm{d}^{-1}$, coinciding with a rapid decline in phytoplankton biomass, cell volume and chlorophyll a concentration. In winter (late April to September), phytoplankton abundance and productivity were insufficient to sustain extensive herbivory; only 5 of the 12 winter experiments yielded microzooplankton grazing rates that were significantly different from zero. The few significant experiments showed that microheterotrophs occasionally consumed ca. $54 \%$ of the phytoplankton standing stock and $>100 \%$ primary production $\mathrm{d}^{-1}$. In spring (October to November), rates of microzooplankton grazing and phytoplankton growth were highly significant but negative. Our study showed that microzooplankton contributed substantially to the termination of the summer phytoplankton bloom. Thereafter, microzooplankton grazing, though occasionally substantial, was commonly low or insignificant. Furthermore, during the aphotic Antarctic winter, negative rates of phytoplankton growth commonly exceeded those of microzooplankton grazing, suggesting that herbivory was not the principal cause of phytoplankton mortality.
\end{abstract}

KEY WORDS: Antarctic $\cdot$ Microzooplankton $\cdot$ Grazing $\cdot$ Phytoplankton growth Resale or republication not permitted without written consent of the publisher

\section{INTRODUCTION}

Understanding energy flow in the marine microbial community is vital to developing global carbon budgets (e.g. Legendre \& Le Fevre 1995). Microzooplankton are ubiquitous, diverse and can be abundant in Antarctic waters (Burkhill et al. 1995, Becquevort et al. 2000). Their grazing can be the dominant source of prey mortality, regulating the concentration and activity of bacterioplankton and the abundance, size structure and species composition of phytoplankton (Froneman \& Perissinotto 1996, Li et al. 2001, Calbet \& Landry 2004). Microzooplankton grazing can also (1) contribute as much to microbial community respiration as bacterioplankton, (2) affect phytoplankton and bacterial productivity by remineralising nutrients and releasing dissolved organic carbon (DOC), and (3) play a crucial role in the transfer of carbon to higher trophic levels (e.g. Burkhill et al. 1995, Strom et al. 1997, Calbet \& Landry 2004), with ramifications for global climate (Froneman et al. 1996, Becquevort et al. 2000, Rivkin \& Legendre 2001).

Each method of estimating rates of microzooplankton grazing has inherent weaknesses and ambiguities (Landry 1994). The dilution grazing technique of Landry \& Hassett (1982) is now a widely applied and 
accepted method of determining rates of microzooplankton grazing (e.g. Calbet \& Landry 2004, Dolan \& McKeon 2005). The assumptions inherent in the technique have been closely scrutinized since its introduction. Various shortcomings have been identified, many of which have been addressed by refinements of the method (e.g. Landry et al. 1995, Gallegos et al. 1996, Dolan et al. 2000, Dolan \& McKeon 2005). Unlike other techniques, grazing dilution has the advantages that it uses predators and prey whose composition and palatability is unchanged; it simultaneously estimates rates of phytoplankton growth and microzooplankton grazing for entire microbial communities, and it minimises experimental manipulations that can damage protists (Landry 1993, 1994, Kuipers \& Witte 1999). Thus, the grazing dilution technique remains one of the most informative yet least invasive and damaging techniques available.

The extent to which microzooplankton grazing limits the abundance and production of Antarctic phytoplankton is equivocal. A number of grazing dilution studies have been conducted in the Southern Ocean (e.g. Taylor \& Haberstroh 1988, Froneman \& Perissinotto 1996, Froneman et al. 1996, Tsuda \& Kawaguchi 1997, Caron et al. 2000). Some report that grazing rates are low and/or are frequently undetectable (Fronemann \& Perissinotto 1996, Tsuda \& Kawaguchi 1997, Kuipers \& Witte 1999, Caron et al. 2000). Others find that microzooplankton abundance and grazing rates are high and may be sufficient to explain the low biomass of phytoplankton over much of the Southern Ocean (Froneman et al. 1996, Tsuda \& Kawaguchi 1997, Anderson \& Rivkin 2001, Calbet \& Landry 2004, Dolan \& McKeon 2005). The apparent conflict between such studies suggests that microzooplankton grazing rates vary greatly with place and time (Caron et al. 2000, Calbet\& Landry 2004).

Most studies of microzooplankton grazing in the Southern Ocean have been performed in offshore waters during summer. Studies in the marginal ice zone are less common (e.g. Froneman et al. 1996), despite these waters contributing 25 to $67 \%$ of phytoplankton production in the Southern Ocean (Smith \& Nelson 1986). In addition, few grazing dilution studies report seasonal changes in phytoplankton growth and mortality and, to our knowledge, none encompass winter. Extreme seasonal fluctuations of productivity in Antarctic waters impose large changes in microbial abundance, composition and trophodynamics (Delille 2004). Thus, rates of phytoplankton growth and grazing during summer are likely to differ greatly from those in winter. Such information is important to accurately model carbon flow in Antarctic waters and to understand constraints on the composition and abundance of phyto- plankton that initiates the spring bloom (Becquevort et al. 2000).

The present study reports rates of phytoplankton growth and mortality in near-shore Antarctic waters from February to November 2004.

\section{MATERIALS AND METHODS}

Sample collection. Sampling was conducted approximately every 2 wk between 16 February and 23 November 2004 at O'Gorman Rocks, ca. 1 km offshore from Davis Station, Antarctica $\left(68^{\circ} 35^{\prime} \mathrm{S}, 7^{\circ} 58^{\prime} \mathrm{E}\right)$ (Fig. 1). The sampling site was ca. $22 \mathrm{~m}$ deep and covered by sea-ice from late March until the end of the sampling period. Samples were collected from $5 \mathrm{~m}$ using a darkened Kammerer bottle, either from an inflatable rubber boat during ice-free periods, or through a $240 \mathrm{~mm}$ diameter hole drilled through the sea-ice. On each sampling occasion, water was collected into darkened 201 carboys and grazing dilution experiments were started within $2 \mathrm{~h}$ of collection. Water temperature and photosynthetically active radiation (PAR) were also recorded at $5 \mathrm{~m}$ using a YSI 6600 sonde (YSI).

Grazing dilution. The method used was an adaptation of the grazing dilution experiment outlined in Landry \& Hassett (1982). Water collected from O'Gorman Rocks was filtered through a $200 \mu \mathrm{m}$ mesh to

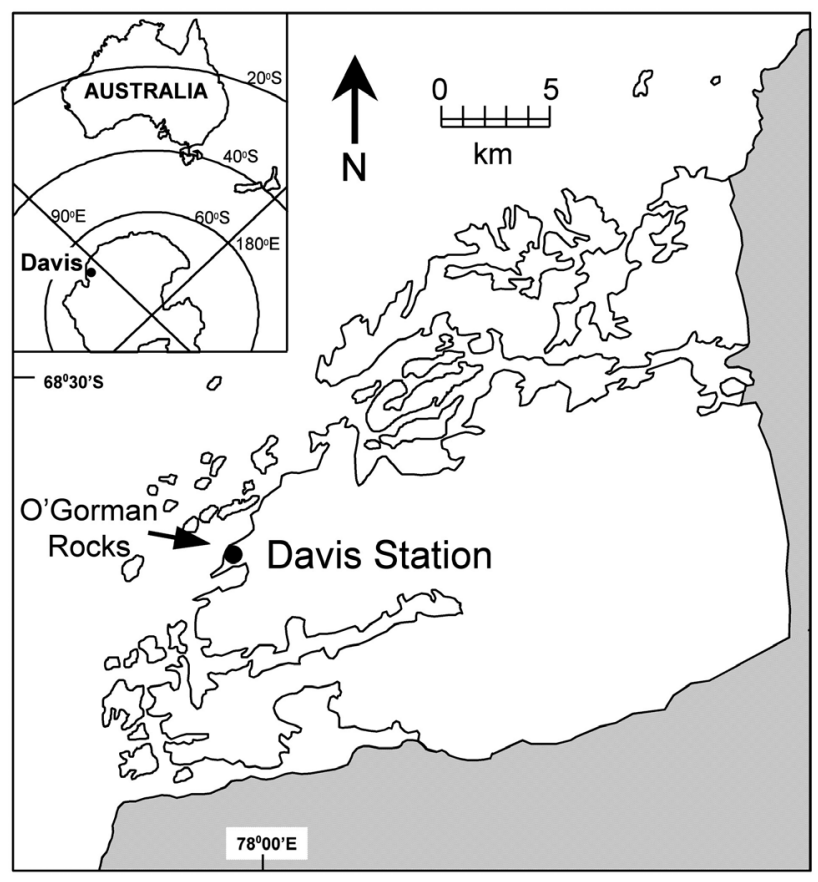

Fig. 1. Location of Davis Station on the East Antarctic coastline and the sample site at O'Gorman Rocks. Shaded areas are permanently ice-covered land 
remove large zooplankton and gently transferred into $2.4 \mathrm{l}$, HCl-washed polycarbonate bottles. A dilution gradient of $100,70,40$ and $10 \%$ seawater was established in triplicate using diluent prepared by filtering seawater from the sample site through a $0.2 \mu \mathrm{m}$ Supor (Gelman) inline filter. The dilution series, together with one bottle containing only diluent (blank), were incubated in a cool room at $1.7 \pm 0.1^{\circ} \mathrm{C}$ for $24 \mathrm{~h}$ exposed to a 12:12 h light:dark cycle at PAR irradiance similar to that measured beneath the ice in early spring $(5 \mu \mathrm{mol}$ $\mathrm{m}^{-2} \mathrm{~s}^{-1}$ ). Unlike Landry \& Hassett (1982), nutrients were not added to bottles containing diluent as macroand micro-nutrients are not regarded as limiting microbial productivity in Antarctic coastal waters (e.g. Odate \& Fukuchi 1995).

At the beginning of the experiment $\left(T_{0}\right)$, known volumes (ca. 1 l) of seawater from 3 undiluted samples were transferred to darkened bottles and filtered onto a $13 \mathrm{~mm}$ diameter $\mathrm{GF} / \mathrm{F}$ filter and stored frozen at $-80^{\circ} \mathrm{C}$ at Davis Station. Following the $24 \mathrm{~h}$ incubation period, all remaining samples in the dilution series and the bottle containing diluent were filtered and stored as above. Cryovials were transferred to liquid nitrogen during transport to Australia and subsequently stored in an ultra low freezer at $-135^{\circ} \mathrm{C}$ until analysed.

Pigments. Pigments were extracted from GF/F filters (see above) by sonication in $1.8 \mathrm{ml}$ of $\mathrm{MeOH}$ to which $176 \mu \mathrm{g}$ of apo-8'- $\beta$-carotenal (Fluka) was added as an internal standard. The extract was filtered through a $0.45 \mu \mathrm{m}$ inline filter and pigments were identified by HPLC using the methods of Zapata et al. (2000). Hardware included a 626 LC pump (Waters), a Waters Symmetry C8 column $(250 \times 4.6 \mathrm{~mm}, 5 \mu \mathrm{m}$ bead size $)$, a Waters 996 photodiode array and F1000 fluorescence detectors (Hitachi). Millenium 32 (v. 3.05.01) and Waters Empower build 1154 software was used in the acquisition and processing of data. Pigments were identified by comparison with authentic pigment spectra from the Scientific Committee on Oceanic Research (SCOR) reference cultures (Jeffrey \& Wright 1997), and by comparison of retention times of a mixture of standard pigments that was analysed daily. Pigments were quantified following the internal standard method of Mantoura \& Repeta (1997), after isolation of individual pigments from SCOR cultures and spectrophotometric quantitation in standard solvents (Jeffrey \& Wright 1997). The mean and standard error of chlorophyll a $(\mathrm{chl} a)$ concentration was calculated at each sample time and the dilution 'blank' subtracted from the diluted sample results prior to data processing.

Protists. Microzooplankton concentrations and the identification of dominant phytoplankton at each sampling interval were determined at the beginning of each experiment. A 11 sub-sample was removed from the carboy (see above), preserved with $2 \%$ vol:vol acid Lugol's iodine, sedimented in a measuring cylinder for $\geq 4 \mathrm{~d}$ and then concentrated to $40 \mathrm{ml}$. To aid identification of protists, samples of concentrate were pipetted onto formvar-coated copper grids, fixed for $60 \mathrm{~s}$ with $2 \% \mathrm{OsO}_{4}$ vapour, rinsed with distilled water, air dried and shadow cast with chromium metal. Shadow-cast preparations were then examined using a Phillips CM 100 transmission electron microscope (TEM). Autoand heterotrophic organisms were discriminated by microscopy using the methods of Davidson \& Belbin (2002). Two or 3 replicate $10 \mathrm{ml}$ subsamples were then settled in sedimentation chambers and 10 to 15 fields of view ( $\geq 100$ cells) counted using a Zeiss Axiovert inverted microscope equipped with Nomarski optics at 100x and 400x magnification. Light and electron microscopy was used to identify microzooplankton and dominant phytoplankton to genus and species level when possible. The mean and standard error of cell concentrations were then calculated for each taxon.

Due to low concentrations of microzooplankton during winter, both measured cell dimensions and taxonspecific cell sizes from the literature (Scott \& Marchant 2005 ) were used to calculate biovolume using the formulae in Hillebrand et al. (1999). Where not incorporated in the biomass conversion factors (heterotrophic dinoflagellates and all other protists), volumes of preserved cells were multiplied by 1.33 to compensate for Lugol's-induced cell shrinkage (Dehairs et al. 1992). The average biovolume of auto- or heterotrophic protists at each sample time was calculated by dividing the total biovolume of auto- or heterotrophs at each sample time by their concentration.

Taxon-specific cell concentrations and biovolumes were used to calculate carbon biomass using the conversion statistics: $0.19 \mathrm{pg} \mathrm{C} \mathrm{mm}^{-3}$ for ciliates (Putt \& Stoeker 1989); $0.183 \mathrm{pg} \mathrm{C} \mathrm{mm}^{-3}$ for heterotrophic

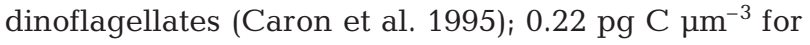
heterotrophic nanoflagellates (Børsheim \& Bratak 1987); and pg $\mathrm{C}=0.109 \times(\text { cell volume })^{0.991}$ for all other protists (Montagnes et al. 1994). The ratio of total autotrophic:heterotrophic biomass at each sample time was then calculated.

Data analysis. The apparent growth rates $(r)$ in each bottle on each sampling occasion were calculated based on chl a measurements from the dilution series, using the equation of Landry et al. (1995):

$$
r=\ln \left(N_{t} / N_{0}\right) / t
$$

where $N_{t}$ and $N_{0}$ are the concentration of chl $a$ at the beginning and end of the grazing incubation, respectively, and $t$ is the duration of the incubation in days.

Coefficients of phytoplankton growth $(\mu)$ and microzooplankton grazing $(g)$ were determined from least 
squares linear regression analysis of apparent growth rates versus the fraction of unfiltered water in each bottle. The slope of the regression represented the rate of grazing mortality and the $y$-intercept represented the growth rate of phytoplankton.

Relationships between seasonal changes in environmental variables (temperature, sea-ice thickness and PAR), chl $a$ and microzooplankton concentrations were explored with Pearson correlation coefficients.

The percentage of standing stock and primary production grazed was calculated using the equations of Safi et al. (2007):

$$
\begin{aligned}
& \% \text { standing stock grazed }=\left(1-\mathrm{e}^{-g}\right) \times 100 \\
& \% \text { production grazed }=100 \times\left(1-\mathrm{e}^{-g}\right) /\left(\mathrm{e}^{\mu}-1\right)
\end{aligned}
$$

where $\mathrm{e}=$ base $\mathrm{e}$

\section{RESULTS}

\section{Physical parameters}

Temperature and PAR profiles recorded from O'Gorman Rocks between 16 February and 23 November 2004 are presented elsewhere (Pearce et al. 2007), but are briefly documented here (Table 1). Low PAR was recorded (18 to $27 \mu \mathrm{mol} \mathrm{m} \mathrm{m}^{-2} \mathrm{~s}^{-1}$ ) at $5 \mathrm{~m}$ during March and April despite day lengths of around 15 to $8 \mathrm{~h}$, owing to substantial cloud cover at the time of sampling. From late March, sea ice formed and thickened and day length solar zenith angles declined, coinciding with a further reduction in PAR to less than $10 \mu \mathrm{mol} \mathrm{m}{ }^{-2} \mathrm{~s}^{-1}$ by 20 April 2004. Between 1 June and 10 August 2004, irradiances of PAR at $5 \mathrm{~m}$ depth were below the limits of detection and day lengths ranged from 0 to $6.5 \mathrm{~h}$. At the end of the sampling period (23 November 2004) day length was ca. $23 \mathrm{~h}$ and PAR had increased to $172 \mu \mathrm{mol} \mathrm{m} \mathrm{m}^{-2} \mathrm{~s}^{-1}$, despite a sea-ice thickness of $1.87 \mathrm{~m}$. Ambient water temperature at $5 \mathrm{~m}$ ranged from a maximum of $0.34^{\circ} \mathrm{C}$ on 16 February to a minimum of $-2.11^{\circ} \mathrm{C}$ on 2 November.

\section{Phytoplankton growth and mortality}

During February and March, when the sample site was ice free and chl a, PAR and water temperatures were high, phytoplankton growth exceeded grazing mortality. Phytoplankton growth rates ranged from 0.503 to $0.814 \mathrm{~d}^{-1}$ and microzooplankton grazing rates ranged from 0.273 to $0.545 \mathrm{~d}^{-1}$ (Table 1). Grazers removed between 24 and $33 \%$ of the phytoplankton standing stock and 27 to $40 \%$ primary production $\mathrm{d}^{-1}$.
The dilution experiment conducted on 6 April 2004 was the first conducted after the sea-ice formed. At this time, grazing rates were exceptionally high and phytoplankton growth rates very low, resulting in the apparent removal by microzooplankton of $762 \%$ primary production and $72 \%$ of the standing stock $\mathrm{d}^{-1}$ (Table 1).

Only 5 of the 12 experiments conducted in late autumn and winter (20 April to 21 September 2004) produced significant regressions of apparent phytoplankton growth against dilution factor (Table 1). Concentrations of chl a were very low (0.03 to $0.61 \mu \mathrm{g} \mathrm{l}^{-1}$ ) (Table 1) and growth rates were negative on all but 3 occasions. In significant experiments, average rates of phytoplankton growth and grazing mortality were $-0.53 \pm 0.21$ and $0.37 \pm 0.16 \mathrm{~d}^{-1}$, respectively, and rates of grazing were commonly less than rates of phytoplankton loss in the absence of grazing. Grazing removed 35 to $79 \%$ of the phytoplankton standing stock $\mathrm{d}^{-1}$ and on the occasions when phytoplankton growth rates were positive (during August), microzooplankton grazing removed between 119 and $155 \%$ of primary production $\mathrm{d}^{-1}$ (Table 1).

Experiments conducted between October and November gave results that were significant, but showed both negative phytoplankton growth and negative grazing mortality. The average rate of phytoplankton growth was $-1.78 \pm 0.78 \mathrm{~d}^{-1}$ and grazing mortality was $-1.07 \pm 0.25 \mathrm{~d}^{-1}$. This coincided with increasing PAR values and an increase in chl a to between 1.7 and $6.8 \mu \mathrm{g} \mathrm{l}^{-1}$.

\section{Phytoplankton and microzooplankton biomass}

The mean chl a concentration in mid-February was $9.9 \mathrm{\mu g} \mathrm{l}^{-1}$ (Table 1) and the phytoplankton community was dominated by large diatoms including Corethron criophilum, Chaetoceros spp., Eucampia antarctica, Odontonella litigiosa, Navicula spp. and Fragilariopsis spp. (data not shown). Chl a rapidly declined in March, continued to decline during April and May and remained very low over the remainder of winter $(<0.03$ to $0.13 \mu \mathrm{g} \mathrm{l}^{-1}$ ) (Table 1). A peak in chl a of $6.8 \mu \mathrm{g} \mathrm{l}^{-1}$ occurred on 25 October 2004 (Table 1), coinciding with increased concentrations of the ice-associated diatoms Entomoneis kjellmanii and Navicula spp. (data not shown). Concentrations then declined to ca. $2 \mu \mathrm{g} \mathrm{l} \mathrm{l}^{-1}$, but increased to $5.3 \mathrm{\mu g} \mathrm{l}^{-1}$ on 23 November 2004, coinciding with increased concentrations of the dinoflagellate Polarella glacialis.

The euglenid Anisoma prosgeobium dominated the microzooplankton for much of the year, while species of Strombidium, Gyrodinium, Protoperidinum and tintinnids were also major contributors to the micro- 
Table 1. Temperature, photosynthetically active radiation (PAR), ice thickness, chlorophyll $a$, rates of grazing mortality ( $g$ ) and phytoplankton growth $(\mu)$, percentage primary production and phytoplankton standing stock removed measured at O'Gorman Rocks between 16 February and 23 November 2004 . Significant results are ${ }^{*} p<0.05$ or ${ }^{* *} p<0.01$; ns: non-significant. na: not applicable

\begin{tabular}{|c|c|c|c|c|c|c|c|c|c|}
\hline $\begin{array}{l}\text { Date } \\
(2004)\end{array}$ & $\begin{array}{l}\text { Temp } \\
\left({ }^{\circ} \mathrm{C}\right)\end{array}$ & $\begin{array}{c}\text { PAR } \\
(\mu \mathrm{mol} \\
\left.\mathrm{m}^{-2} \mathrm{~s}^{-1}\right)\end{array}$ & $\begin{array}{l}\text { Day } \\
\text { length } \\
\text { (h) }\end{array}$ & $\begin{array}{l}\text { Ice } \\
\text { thickness } \\
\text { (cm) }\end{array}$ & $\begin{array}{c}\text { Chl a } \\
\left(\mu \mathrm{g} \mathrm{l}^{-1}\right)\end{array}$ & $\frac{g}{\left(d^{-1}\right)}$ & $\begin{array}{c}\mu \\
\left(d^{-1}\right)\end{array}$ & $\begin{array}{c}\% \\
\text { primary } \\
\text { production }\left(\mathrm{d}^{-1}\right)\end{array}$ & $\begin{array}{c}\% \text { phyto- } \\
\text { plankton } \\
\text { standing stock }\left(\mathrm{d}^{-1}\right)\end{array}$ \\
\hline 16 Feb & 0.34 & na & 16.98 & 0 & 9.88 & $0.27^{*}$ & 0.50 & 37 & 24 \\
\hline 2 Mar & -1.08 & 18.4 & 14.77 & 0 & 6.61 & $0.55^{*}$ & 0.72 & 40 & 42 \\
\hline $12 \mathrm{Mar}$ & -1.82 & 26.7 & 13.38 & 2 & 3.69 & $0.41^{* *}$ & 0.81 & 27 & 33 \\
\hline $6 \mathrm{Apr}$ & -1.84 & 20.7 & 10.03 & 33.8 & 0.75 & $1.13^{* *}$ & 0.09 & 762 & 72 \\
\hline $20 \mathrm{Apr}$ & -1.84 & 7.0 & 8.12 & 45.8 & 0.41 & -0.25 & -0.73 & ns & ns \\
\hline 7 May & -1.86 & 0.1 & 5.70 & 54.8 & 0.61 & -0.17 & -1.93 & ns & ns \\
\hline 18 May & -1.87 & 0.1 & 3.97 & 67 & 0.24 & $0.55^{* *}$ & -0.65 & -89 & 42 \\
\hline 1 Jun & -1.99 & 0 & 0.90 & 72.6 & 0.47 & $0.65^{*}$ & -1.04 & -74 & 48 \\
\hline 15 Jun & -2.00 & 0 & 0.00 & 89.5 & 0.13 & $1.15^{* *}$ & -0.03 & -2706 & 68 \\
\hline 29 Jun & -1.99 & 0 & 0.00 & 105.4 & 0.06 & 0.04 & -0.44 & ns & ns \\
\hline $13 \mathrm{Jul}$ & -2.00 & 0 & 1.70 & 111.9 & 0.06 & 0.64 & 0.44 & ns & ns \\
\hline $29 \mathrm{Jul}$ & -2.01 & 0 & 4.67 & 124.2 & 0.09 & -0.11 & -1.09 & ns & ns \\
\hline 10 Aug & -2.02 & 0 & 6.47 & 132 & 0.03 & $0.43^{*}$ & 0.26 & 119 & 35 \\
\hline 24 Aug & -2.02 & 0.2 & 8.40 & 136.8 & 0.06 & $1.54^{* *}$ & 0.41 & 155 & 79 \\
\hline 7 Sep & -2.02 & 1.5 & 10.27 & 146.6 & 0.04 & -0.12 & -1.11 & ns & ns \\
\hline $21 \mathrm{Sep}$ & -2.03 & 4.0 & 12.12 & 151.5 & 0.03 & 0.05 & -0.54 & ns & ns \\
\hline 5 Oct & -2.01 & 5.6 & 13.98 & 160 & 1.70 & $-1.31^{* *}$ & -1.10 & na & na \\
\hline 25 Oct & -2.06 & 22.9 & 13.85 & 164 & 6.79 & $-1.18^{* *}$ & -2.82 & na & na \\
\hline $2 \mathrm{Nov}$ & -2.11 & 12.7 & 18.12 & 165 & 2.77 & $-1.05^{* *}$ & -1.94 & na & na \\
\hline $16 \mathrm{Nov}$ & -2.11 & 72.0 & 20.77 & 164.4 & 1.85 & $-0.73^{* *}$ & -1.28 & na & na \\
\hline $23 \mathrm{Nov}$ & -2.04 & 172.3 & 22.73 & 187.5 & 5.28 & -0.01 & -0.55 & ns & ns \\
\hline
\end{tabular}

zooplankton community (Fig. 2A). Eutreptiella spp., Psuedocohnilembus spp. and Euplotes spp. were lesser contributors and were grouped together as 'other protozoa'.

Microzooplankton were most abundant during summer, rapidly declined in early March, continued to decline over the remainder of winter and only began to increase after mid-November (Fig. 2). The only exception was the euglenid Anisoma prosgeobium, which dominated the microzooplankton for much of the year and peaked intermittently over winter. Concentrations of Anisoma prosgeobium, tintinnids and heterotrophic dinoflagellates (Gyrodinium and Protoperidinum) were highest between February and March (Fig. 2A,B). Concentrations of Strombidium spp., other protists and heterotrophic nanoflagellates were highest the following summer (late November to late December) (Fig. 2C). Microzooplankton were only observed sporadically in Lugol's preserved samples and standard errors, though occasionally low (ca. 17\%), were commonly similar to mean concentrations.

Most heterotrophic nanoflagellates were not identifiable to species level in fixed samples by light microscopy. However, between February and April samples were dominated by choanoflagellates (especially Bicosta spp.), with Cryothecomonas armigera and unidentified dinoflagellates also abundant (data not shown). During the winter months, the heterotrophic community largely comprised other dinoflagellates, haptophytes and bodonids. The increase in heterotrophic nanoflagellates at the end of spring (October to November) was predominantly due to Leucocryptos marina, with concentrations reaching ca. $4.19 \times 10^{5} \mathrm{l}^{-1}$ (Fig. 2).

\section{Cell size and biomass}

Seasonal variations were observed in the average cell size and biomass of protists. In late summer and early autumn (February to March) the average cell volume of microzooplankton increased approximately 10-fold (Fig. 3A) and biomass of phytoplankton and microzooplankton was the highest observed during the study (Fig. 3B,C). However, the cell volume of phytoplankton and ratio of autotrophic:heterotrophic (Auto:Het) biomass declined (Fig. 3A,D). As sea-ice formed on 6 April, the biomass of phytoplankton, microzooplankton, and the ratio of Auto:Het biomass declined greatly. Between late autumn (20 April) and early spring (21 September) both the average cell volume and total biomass of phytoplankton remained low; however, the average cell volume of microzooplankton varied from ca. 4800 to $30000 \mu^{3}$ and the biomass ranged from 6.3 to $96.0 \mu \mathrm{g} \mathrm{Cl}^{-1}$. On 5 October, average 

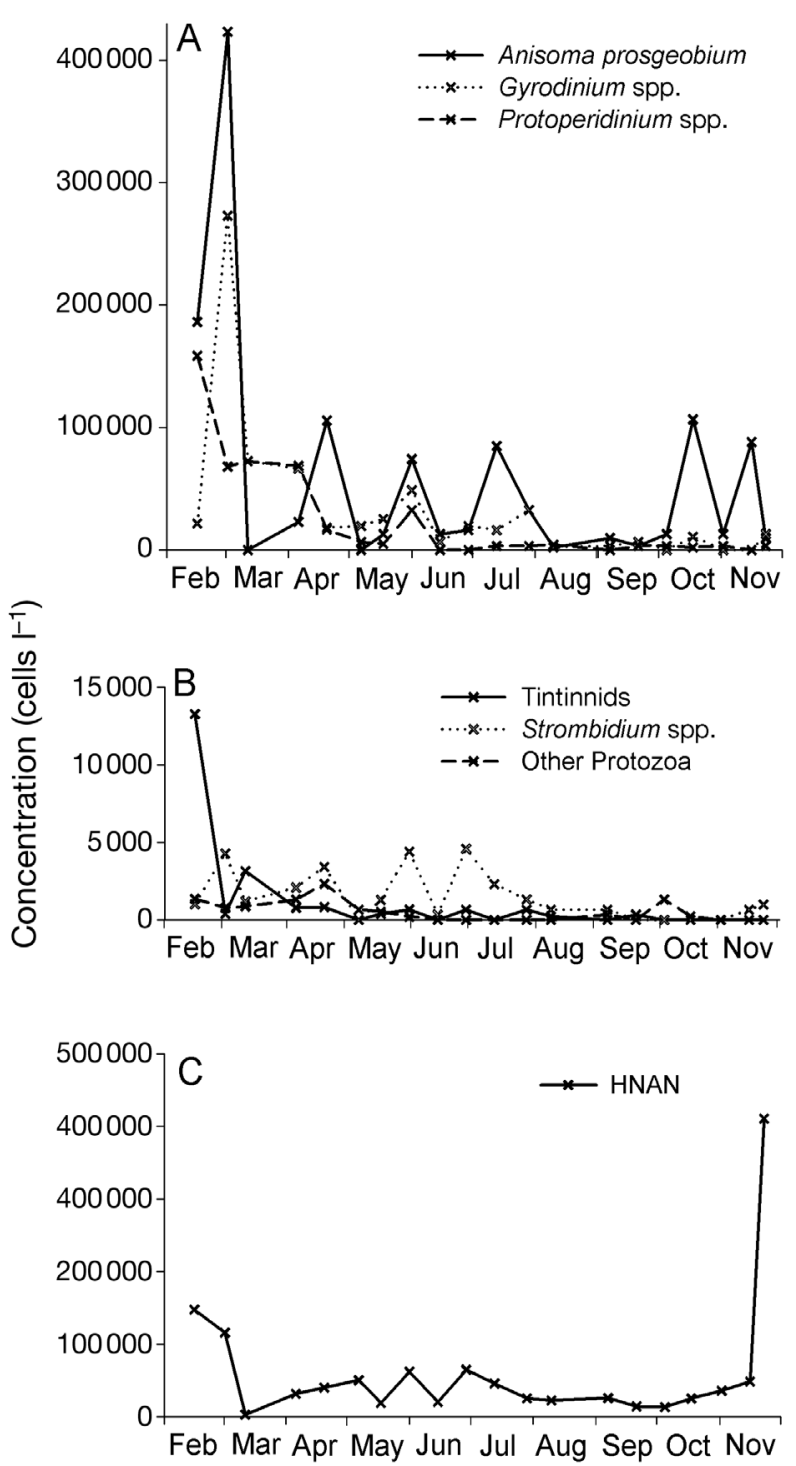

Fig. 2. Concentrations of microzooplankton taxa/groups at O'Gorman Rocks between 16 February and 23 November 2004. HNAN: heterotrophic nanoflagellates. Variances were commonly similar to mean concentrations and are not presented

autotroph cell volume suddenly increased 10-fold, reaching values similar to the maximum in summer (Fig. 3A). This coincided with a decline in average heterotrophic cell volumes to $<5000 \mu^{3}$ (Fig. 3A) and around a 100-fold increase in the ratio of Auto:Het biomass, reaching values 4.8 times higher than on any other sampling occasion (Fig. 3D). The average cell volume of autotrophs then declined to around that during winter; the ratio of Auto:Het biomass declined to values similar to those in the previous summer, but average heterotrophic cell volume and biomass remained low (Fig. 3).
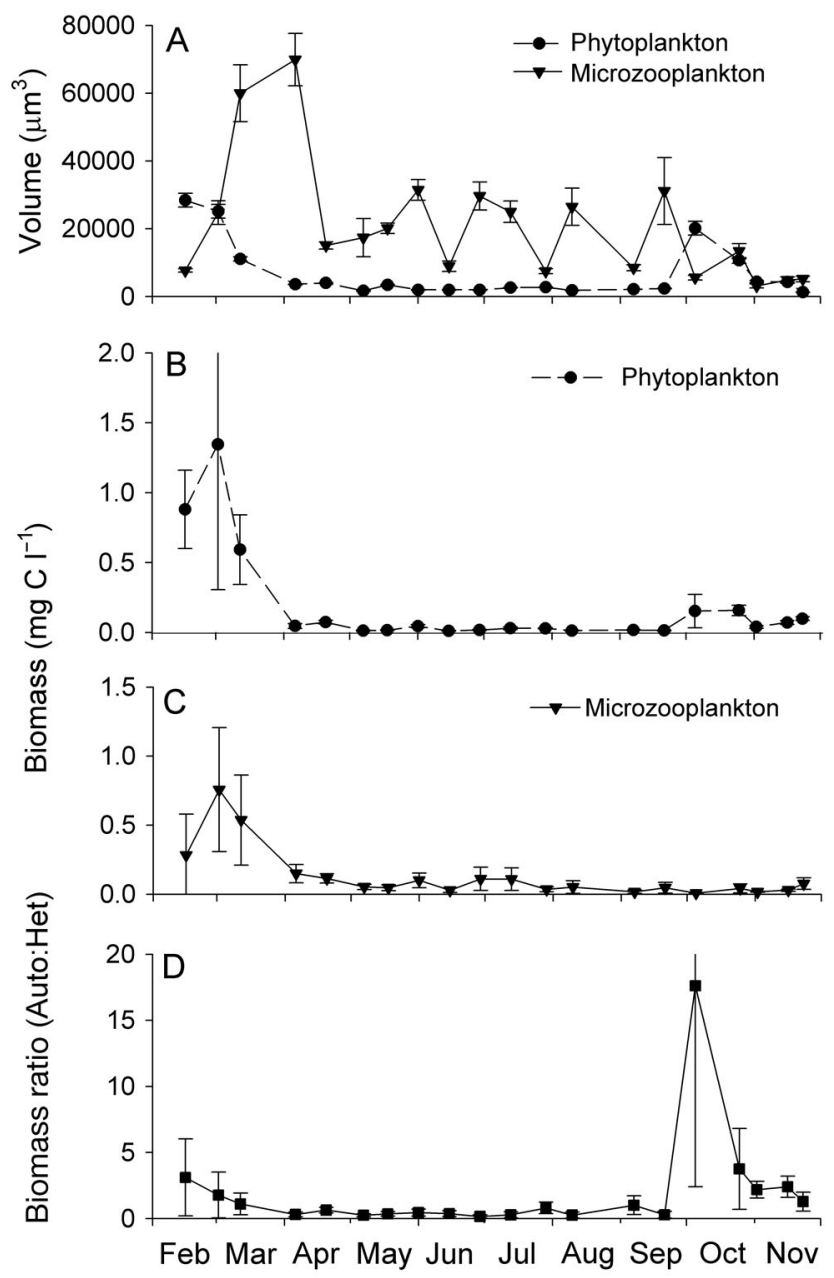

Fig. 3. Changes in the (A) phytoplankton and microzooplankton average cell volume, (B) phytoplankton carbon biomass, (C) microzooplankton carbon biomass and (D) ratio of autotrophic:heterotrophic (Auto:Het) carbon biomass at O'Gorman Rocks between 16 February and 23 November 2004. Error bars represent $\pm 1 \mathrm{SE}$

\section{Seasonal correlations}

Between February and November 2004, concentrations of microzooplankton were correlated $(p<0.05)$ with chl a concentrations and PAR but not with water temperature or ice thickness (Table 2). Concentrations of chl a were also significantly correlated to PAR and water temperature but not ice thickness. Rates of microzooplankton grazing and phytoplankton growth were significantly correlated $(\mathrm{p}<0.05)$ over experiments that produced significant regressions of apparent phytoplankton growth against dilution (Table 2). No seasonal correlations were found between grazing mortality or phytoplankton growth and chl $a$, grazer concentrations or any of the environmental variables measured except ice thickness. 
Table 2. Pearson's correlation coefficients (r) of microzooplankton grazing and phytoplankton growth rates with measured environmental and biological parameters. Significant values $(p<0.05)$ are in bold, degrees of freedom are in parentheses

\begin{tabular}{|c|c|c|c|c|c|c|}
\hline & Microzooplankton & Chl a & Temp. $\left({ }^{\circ} \mathrm{C}\right)$ & PAR & Ice thickness & Grazing rate \\
\hline Phytoplankton growth rate & $0.39(11)$ & $-0.01(11)$ & $0.44(11)$ & $-0.21(11)$ & $-0.72(11)$ & $0.75(11)$ \\
\hline Microzooplankton grazing rate & $0.2(11)$ & $-0.33(11)$ & $0.14(11)$ & $-0.38(11)$ & $-0.56(11)$ & \\
\hline Ice thickness & $-0.02(19)$ & $-0.25(19)$ & $0.62(19)$ & & & \\
\hline PAR & $0.84(19)$ & $0.53(19)$ & $-0.09(19)$ & & & \\
\hline Temp. $\left({ }^{\circ} \mathrm{C}\right)$ & $0.38(19)$ & $0.71(19)$ & & & & \\
\hline Chl a & 0.59 (19) & & & & & \\
\hline
\end{tabular}

\section{DISCUSSION}

We found significant correlations between biotic variables and between the biota and physical factors during our study. Chl a concentrations were significantly correlated with seasonal changes in PAR and water temperature and microzooplankton abundance was correlated with PAR. Such correlations are unsurprising as changes in Antarctic light climate and biological productivity are among the most seasonal in the world (Delille 2004). However, the covariance of environmental variables during the study meant it was not possible to determine causal relationships between any specific physical factor and protist concentrations.

We also found significant correlations between concentrations of microzooplankton and chl $a$ and between rates of microzooplankton grazing and phytoplankton growth. These are common relationships in Antarctic waters (Froneman \& Perissinotto 1996, Caron et al. 2000, Safi et al. 2007). However, most Antarctic grazing dilution experiments are conducted from transects taken during summer voyages that report differences among sampling sites rather than through time (Taylor \& Haberstroh 1988, Froneman \& Perissinotto 1996, Froneman et al. 1996). Thus, to our knowledge, there are no Antarctic studies using the grazing dilution technique with which we can directly compare our seasonal data.

The logistical difficulties of conducting such studies during the extremes of winter meant that we had to perform incubation of our grazing dilution bottles in a cold room rather than in situ. Bottles were incubated at a temperature $\left(1.7^{\circ} \mathrm{C}\right)$ that was on average $3.5^{\circ} \mathrm{C}$ higher than the natural environment and were exposed to $12: 12 \mathrm{~h}$ light:dark cycle at a consistent low PAR irradiance $\left(5 \mu \mathrm{mol} \mathrm{m} \mathrm{m}^{-2} \mathrm{~s}^{-1}\right)$. It is possible that the use of a constant incubation environment affected the rates of herbivory and the growth of phytoplankton and microzooplankton (see below) and reduced their seasonal oscillation during this study.

The irradiance to which the dilution bottles were exposed was equivalent to that measured at $5 \mathrm{~m}$ depth beneath the sea-ice in late September and early Octo- ber. Grazing dilution studies are characteristically performed under subdued light (Gallegos et al. 1996, Caron et al. 2000, Strom et al. 1997, Safi et al. 2007). The irradiance used was appropriate for incubations performed in late summer and early spring, being around a quarter to half that measured prior to early April and between late October and early November. It was higher than that in winter and exceeded the very low $\left(0.1\right.$ to $\left.0.15 \mu \mathrm{mol} \mathrm{m} \mathrm{m}^{-2} \mathrm{~s}^{-1}\right)$ compensation intensities for phytoplankton beneath sea ice (e.g. Cota 1985, Brightman \& Smith 1989). However, the low and negative growth rates of phytoplankton after late April (see below) suggested that their physiological state was poor and that they were unable to capitalise on the available radiation. Furthermore, Fiala \& Oriol (1990) found that the growth rate of Antarctic diatoms was mainly determined by temperature rather than the light climate and Rose \& Caron (2007) suggest that in polar waters, photoperiod duration does not significantly affect protistan growth rates over periods $\sim 24 \mathrm{~h}$. Only in mid- to late November was the incubation irradiance only a small fraction of that measured, potentially reducing rates of phytoplankton growth in incubations relative to those in situ.

Most studies in polar waters show that rates of herbivory are independent of temperature (Froneman \& Perissinotto 1996, Sherr et al. 1997, Tsuda \& Kawaguchi 1997). In addition, Caron et al. (2000) found that differences in rates of microzooplankton grazing were not significant at temperature $<8^{\circ} \mathrm{C}$. Thus, any increase in the rate of microzooplankton grazing as a result of incubating samples at $1.7^{\circ} \mathrm{C}$ is unlikely to be significant.

The effect of the incubation temperature on the growth of phytoplankton and microzooplankton also appears to be minimal. Using the equation of Rose \& Caron (2007), maximum growth rates $\left(\mu_{\max }\right)$ as a function of temperature for cold, high latitude waters indicated that incubation temperature would have enhanced microzooplankton growth by 6 to $7 \%$ (equating to an increase of only 0.03 to 0.04 doublings $\mathrm{d}^{-1}$ ), while phytoplankton growth would have been enhanced 9 to $24 \%$ at the end of summer and on 
average $26 \%$ after March. This value, although significant, is likely to be an overestimate as $\mu_{\max }$ is seldom attained by phytoplankton due to limitation of growth other environmental factors (Smith et al. 1999, Rose \& Caron 2007). Additionally, the insignificant and negative rates of phytoplankton growth we measured suggested that phytoplankton were in a poor physiological state and unable to sustain growth.

Incubating grazing dilution bottles in a cold room may also have led to sedimentation of negatively buoyant phytoplankton, especially diatoms. Rates of microzooplankton grazing amongst sedimented particles would be independent of the experimental dilution, thereby contravening key assumptions of the grazing dilution method and causing apparent grazing rates to decline (Landry et al. 1995). However, we measured high rates of herbivory at the end of summer when the phytoplankton community was dominated by diatoms, suggesting little effect of sedimentation on the rates of herbivory. The low or non-significant rates of herbivory over winter are consistent with the low concentrations of chl $a$ and microheterotrophs. However in spring, aggregates released from the fast ice were abundant and reportedly sink rapidly (Saito et al. 1998). The resulting contravention of assumptions of the grazing dilution technique may have contributed to the negative rates of phytoplankton growth and grazing at this time.

\section{Summer/autumn}

Microzooplankton consumed 24 to $42 \%$ of the phytoplankton standing stock daily in late summer and early autumn (February to March), equating to between 27 and $40 \%$ of primary production. These rates of grazing mortality were despite the fact that the phytoplankton community was dominated microplanktonic and chain-forming diatoms, which can be unavailable to microzooplankton grazers due to their unpalatability, structure and/or size (Bernard \& Rasssoulzadegan 1990, Froneman \& Perissonotto 1996, Froneman et al. 1996, Gallegos et al. 1996, Kuipers \& Witte 1999, Safi et al. 2007).

The average size of microheterotrophs increased ca. 10 -fold in early autumn. This increase coincided with increased rates of microzooplankton grazing, a rapid decline in average phytoplankton cell volume and declining concentrations of chl a despite increasing rates of phytoplankton growth. Size is known to be an important determinant of prey selection by microzooplankton, with different species displaying different optima (e.g. Kuipers \& Witte 1999, Levinsen et al. 1999). Like Levinsen et al. (1999), our data suggest that the prevalence of large prey in late summer/early autumn favoured the development of a microzooplankton community mainly composed of large taxa (Gyrodinium, Protoperidinium and tintinnids). Such prey-related changes in the size structure of the microzooplankton community have not previously been reported from Antarctic waters.

Microzooplankton grazed $72 \%$ of phytoplankton standing stocks but $762 \%$ of primary production as sea-ice began to form on 6 April. Reports of microzooplankton consuming $>100 \%$ primary production are not uncommon (e.g. Tsuda \& Kawaguchi 1997, Safi et al. 2007); however, our result is extraordinarily high. At this time, microzooplankton biomass and abundance was the highest for the year but phytoplankton biomass and growth rates had declined 3- and 9-fold, respectively. As a result, the ratio of Auto:Het biomass (0.13) was the lowest encountered during our study. Such high rates of herbivory alone are sufficient to explain the decline in phytoplankton abundance and it is likely that microzooplankton rapidly consumed the remaining phytoplankton at the onset of winter. However, the 9-fold decline in phytoplankton growth rate between 12 March and 6 April suggests that other factors including physical elements, viral infection or cell lysis (Leist \& Nicotera 1997, Fuhrman 1999) may have limited rates of phytoplankton production at this time.

\section{Winter}

Microzooplankton grazing was non-significant in 7 of the 12 experiments conducted over winter. Non-significant results in grazing dilution studies are common, ranging from around 25 to $80 \%$ of experiments performed (Landry \& Hassett 1982, Murrell \& Hollibaugh 1998, Caron et al. 2000). Such results are widely considered to represent 'zero' grazing or experimental failures and are seldom considered further (Murrell \& Hollibaugh 1998, Kuipers \& Witte 1999, Calbet \& Landry 2004, Dolan \& McKeon 2005). Caron et al. (2000) reported a high percentage of non-significant grazing in Antarctic waters during winter when chl a values were commonly $<0.1 \mu \mathrm{g} \mathrm{l}^{-1}$. Such results can reportedly be due to low concentrations of chl a and microzooplankton, resulting in small herbivoreinduced changes in chl a during experimental incubations (Caron et al. 2000, Dolan \& McKeon 2005). However, Caron et al. (2000) also found that grazing was undetectable when chl a was abundant during a bloom of Phaeocystis, supporting the proposal by Murrell \& Hollibaugh (1998) that the absence of herbivory may also reflect periods when grazers are decoupled from their prey.

Our results suggest that the frequent absence of significant grazing in winter was probably due to the 
absence of prey. We found that the ratio of Auto:Het biomass declined from 3.1 in autumn to an average of 0.51 (and occasionally as low as 0.14 ) during winter, while phytoplankton growth was negative (averaging $-0.54 \pm 0.71$ ). Together, these data show that there was insufficient phytoplankton biomass and production to support extensive herbivory during the aphotic Antarctic winter. It is therefore likely that the lack of phytoplanktonic prey would favour microzooplankton that opportunistically alternated between the most abundant sources of nutrition, thereby reducing or ceasing herbivory by microzooplankton.

The present study, together with a coincident study by Pearce et al. (2007), indicated that alternative sources of nutrition were available during winter. Microzooplankton communities reportedly become dominated by bacterivores and/or herbivores and may switch to bacterivory when phytoplankton abundance is low (Pfister \& Arndt 1998, Anderson \& Rivkin 2001). Pearce et al. (2007) showed that total bacterial concentration remained high in winter, only declining to ca. $30 \%$ of summer concentrations. Bernard \& Rassoulzadegan (1990) reported that bacteria alone are unlikely to support microzooplankton, for which they were sub-optimal prey. Studies at $\mathrm{O}^{\prime}$ Gorman Rocks have shown that concentrations of dissolved organic matter (DOM) vary little over the year and that high molecular weight DOM is abundant in winter (Scott et al. 2000, Pearce et al. 2007). At least some microheterotrophs can directly consume high molecular weight DOM (Sherr 1988). Thus, microzooplankton probably survived winter by opportunistically alternating between sources of nutrition including phytoplankton, bacteria and DOM.

Despite the lack of phytoplankton, $42 \%$ of grazing dilution experiments conducted in winter were significant and showed that phytoplankton growth rates were negative, while grazing mortality was similar to or exceeded that in late summer/early autumn. Such high rates of herbivory in winter may be overestimates due to the low concentrations of grazers and chl $a$ (Dolan \& McKeon 2005). Alternatively, these results may indicate that, at intervals, significant herbivory persisted during winter. Microzooplankton grazing is known to affect the abundance, size structure and species composition of phytoplankton community (Froneman \& Perissinotto 1996, Li et al. 2001, Calbet \& Landry 2004). Given the low standing stocks and commonly negative growth of phytoplankton in winter, such grazing is likely to significantly influence the composition of the phytoplankton community available to initiate the vernal bloom the following summer.

Lysis due to senescence, programmed cell death or viral infection appeared to be a principal fate for autotrophs in Antarctic coastal waters during the extremes of Antarctic winter. Negative rates of phytoplankton growth are frequently reported from dilution grazing experiments but, like non-significant experiments, are seldom considered further (Taylor \& Haberstroh 1988, Landry et al. 1995, Froneman \& Perissinotto 1996, Gallegos et al. 1996, Tsuda \& Kawaguchi 1997, Kuipers \& Witte 1999). We found that rates of decline of phytoplankton in the absence of grazing (negative growth) frequently exceeded rates of microzooplankton grazing. Cell lysis in response to environmental stress or viral infection can be an important loss factor for phytoplankton (Agustí et al. 1998, Fuhrman 1999, Bidle \& Falkowski 2004). The highest rates of negative phytoplankton growth we measured in winter were similar to the maximum rates of phytoplankton lysis measured by Agustí et al. (1998). Thus, during winter, when light is limiting or absent (Delille 2004), much of the phytoplankton mortality may be due to cell lysis.

\section{Spring}

During spring, nearly all grazing dilution experiments gave highly significant results, but both phytoplankton growth and microzooplankton grazing rates were negative. This may be due to the unique environmental conditions and protist community structure at this time. The ratio of Auto:Het biomass was highest at the beginning of spring, but the average cell volume of phytoplankton suddenly increased. Various authors have reported that large phytoplankton are unsuitable prey for microzooplankton (see above). Our results also indicate that microzooplankton appeared to be decoupled from phytoplanktonic prey in spring as the increased abundance of large phytoplankton that had been released from the fast ice coincided with low abundance of microzooplankton that were small and had negative grazing rates. However, though potentially ungrazed, the abundance of large phytoplankton would not cause the negative grazing rates observed in our study.

The reason/s for negative rates of grazing in spring are uncertain as they require net growth rates to decline and be strongly negative at the highest dilutions. Such results are uncommon and past studies have been attributed to deficiencies in methodology (Caron et al. 2000, Calbet \& Landry 2004). Landry (1993) suggested that such negative results may be due to the diluent being toxic to phytoplankton. It is unlikely that our results were due to toxicity as our methods remained unchanged throughout our study and have been successfully employed on subsequent voyages. However, ice algae are likely to have entirely different environmental optima from those in the pelagic environment (Artolozaga et al. 2002) and the 
extent to which they remain active in the water column is unclear (Froneman et al. 1996, Riaux-Gobin et al. 2003). Thus, increasing dilution may elicit an apparently 'toxic' response. Whatever the reason/s, our results showed that the dilution grazing technique was ill-suited to determining rates of microzooplankton grazing in such samples and further work is required to understand these results.

To our knowledge, this is the first temporal study of phytoplankton growth and microheterotroph grazing that encompasses sampling beneath sea-ice over winter. We found that microzooplankton grazing played a vital role in limiting phytoplankton abundance in summer/autumn and in terminating the phytoplankton bloom at the onset of winter, but was a less important cause of phytoplankton mortality during winter. However, microzooplankton grazing was occasionally significant in winter and may fashion the composition and abundance of phytoplankton that initiate the vernal bloom in summer. We also showed that there is insufficient phytoplankton biomass and production to sustain microzooplankton in winter, indicating that omnivory would be required to sustain the nutritional requirements of microzooplankton. In spring, the grazing dilution technique proved inappropriate for quantifying microzooplankton grazing, likely due to the nature and composition of both predators and prey or shortcomings of our methods. Our findings demonstrate the key role of microzooplankton in terminating phytoplankton blooms at the end of summer in Antarctic inshore waters. In contrast, during winter and spring there was insufficient prey to support herbivory and grazing often comprised a small proportion of phytoplankton mortality.

Acknowledgements. We gratefully acknowledge the assistance of the personnel at Davis Station for their support of this research.

\section{LITERATURE CITED}

Agustí S, Satta MP, Mura MP, Benavent E (1998) Dissolved esterase activity as a tracer of phytoplankton lysis: evidence of high phytoplankton lysis rates in the northwest Mediterranean. Limnol Oceanogr 43:1836- 1849

Anderson MR, Rivkin RB (2001) Seasonal patterns in grazing mortality of bacterioplankton in polar oceans: a bi-polar comparison. Aquat Microb Ecol 25:195-206

Artolozaga I, Valcarel M, Ayo B, Latatu A, Iriberri J (2002) Grazing rates of bacterivorous protists inhabiting diverse marine planktonic microenvironments. Limnol Oceanogr 47:142-150

Becquevort S, Menon P, Lancelot C (2000) Differences in the protozoan biomass and grazing during spring and summer in the Indian sector of the Southern Ocean. Polar Biol 23:309-320

Bernard C, Rassoulzadegan F (1990) Bacteria or microflagellates as a major food source for marine ciliates: possible implications for microzooplankton. Mar Ecol Prog Ser 64:147-155

Bidle KD, Falkowski PG (2004) Cell death in planktonic photosynthetic microorganisms. Nat Rev Microbiol 2:643-655

Børsheim KY, Bratak G (1987) Cell volume to cell carbon conversion factors for bacterivorous Monas sp. enriched from seawater. Mar Ecol Prog Ser 36:171-175

Brightman RI, Smith WO Jr (1989) Photosynthesis-irradiance relationships of Antarctic phytoplankton during austral winter. Mar Ecol Prog Ser 53:143-151

Burkill PH, Edwards ES, Sleigh MA (1995) Microzooplankton and their role in controlling phytoplankton growth in the marginal ice zone of the Bellingshausen Sea. Deep-Sea Res 42:1277-1290

Calbet A, Landry MR (2004) Phytoplankton growth, microplankton grazing and carbon cycling in marine systems. Limnol Oceanogr 49:51-57

Caron DA, Dam HG, Kremer P, Lessard EJ and others (1995) The contribution of microorganisms to particulate carbon and nitrogen surface waters or the Sargasso Sea near Bermuda. Deep-Sea Res 42:943-972

Caron DA, Dennett MR, Lonsdale DJ, Moran DM, Shalapyonok L (2000) Microzooplankton herbivory in the Ross Sea, Antarctica. Deep-Sea Res 47:3249-3272

Cota GF (1985) Photoadaptation in high arctic ice algae. Nature 315:219-222

Davidson AT, Belbin L (2002) Exposure of natural Antarctic marine microbial assemblages to ambient UV radiation: effects on the marine microbial community. Aquat Microb Ecol 27:159-174

Dehairs F, Geoyens L, Stroobants N, Mathot S (1992) Elemental composition in the Weddell-Scotia confluence area during spring and summer 1988 (EPOS Leg 2). Polar Biol 12:25-33

Delille D (2004) Abundance and function of bacteria in the Southern Ocean. Cell Mol Biol 50:543-551

Dolan JR, McKeon E (2005) The reliability of grazing rate estimates from dilution experiments: have we over-estimated rates of organic carbon consumption by microzooplankton. Ocean Sci 1:1-7

> Dolan JR, Gallegos CL, Moigis A (2000) Dilution effects on microzooplankton in grazing dilution experiments. Mar Ecol Prog Ser 200:127-139

Fiala M, Oriol L (1990) Light-temperature interactions in the growth of Antarctic diatoms. Polar Biol 10:629-636

Froneman PW, Perissinotto R (1996) Microzooplankton grazing and protozooplankton community structure in the South Atlantic and in the Atlantic sector of the Southern Ocean. Deep-Sea Res I 43:703-721

Froneman PW, Perissinotto R, McQuaid CD (1996) Dynamics of microplankton communities at the ice-edge zone of the Lazarev Sea during a summer drogue study. J Plankton Res 18:1455-1470

Fuhrman JA (1999) Marine viruses and their biogeochemical and ecological effects. Nature 399:541-548

Gallegos CL, Vant WN, Safi KA (1996) Microzooplankton grazing of phytoplankton in Manukau Harbour, New Zealand. NZ J Mar Freshw Res 30:423-434

Hillebrand H, Dürselen CD, Kirschtel D, Pollinger U, Zohary $\mathrm{T}$ (1999) Biovolume calculation for pelagic and benthic microalgae. J Phycol 35:403-424

Jeffrey SW, Wright SW (1997) Qualitative and quantitative HPLC analysis of SCOR reference algal cultures. In: Jeffrey SW, Mantoura RFC, Wright SW (eds) Phytoplankton pigments in oceanography: guidelines to modern methods. SCOR UNESCO, Paris, p 343-360

Kuipers BR, Witte HJ (1999) Grazing impact of microzoo- 
plankton on different size classes of algae in the North Sea in early spring and mid-summer. Mar Ecol Prog Ser 180: 93-104

Landry MR (1993) Estimating rates of growth and grazing mortality of phytoplankton by the dilution method. In: Kemp PF, Sherr BF, Sherr EB, Cole JJ (eds) Handbook of methods in aquatic microbial methods. Lewis Publishers, Boca Raton, FL, p 715-722

Landry MR (1994) Methods and controls for measuring the grazing impact of planktonic protists. Mar Microb Food Webs 8:37-57

Landry MR, Hassett RP (1982) Estimating the grazing impact of marine micro-zooplankton. Mar Biol 67:283-288

Landry MR, Kirshtein J, Constantinou J (1995) A refined dilution technique for measuring the community grazing impact of microzooplankton with experimental tests in the central equatorial Pacific. Mar Ecol Prog Ser 120:53-63

Landry MR, Selph KE, Brown SL, Abbott MR and others (2002) Seasonal dynamics of phytoplankton in the Antarctic Polar Front region at $170^{\circ} \mathrm{W}$. Deep-Sea Res 49: 1843-1865

Legendre L, Le Fevre J (1995) Microbial food webs and the export of biogenic carbon in oceans. Aquat Microb Ecol 9:69-77

Leist M, Nicotera P (1997) The shape of cell death. Biochem Biophys Res Commun 236:1-9

Levinsen H, Nielsen TG, Hansen BW (1999) Plankton community structure and carbon cycling on the western coast of Greenland during the stratified summer situation. II. Heterotrophic dinoflagellates and ciliates. Aquat Microb Ecol $16: 217-232$

Li C, Sun S, Zhang G, Ji P (2001) Summer feeding activities of zooplankton in Prydz Bay, Antarctica. Polar Biol 24:892-900

Mantoura RFC, Repeta DJ (1997) Calibration methods for HPLC. In: Jeffrey SW, Mantoura RFC, Wright SW (eds) Phytoplankton pigments in oceanography: guidelines to modern methods. SCOR UNESCO, Paris, p 407-428

Montagnes DJS, Berges JA, Harrison PJ, Taylor FJR (1994) Estimating carbon, nitrogen, protein, and a chlorophyll a from cell volume in marine phytoplankton. Limnol Oceanogr 39:1044-1060

Murrell MC, Hollibaugh JT (1998) Microzooplankton grazing in northern San Francisco Bay measured by the dilution method. Aquat Microb Ecol 15:53-63

Odate T, Fukuchi M (1995) Physical and chemical properties of surface water in the Southern Ocean in summer 1991/92. Proc NIPR Symp Polar Biol 8:77-85

Pearce I, Davidson AT, Bell EM (2007) Seasonal changes in the concentration and metabolic activity of bacteria and viruses at an Antarctic coastal site. Aquat Microb Ecol 47:11-23

Pfister G, Arndt H (1998) Food selectivity and feeding behaviour in omnivorous filter feeding ciliates: a case study for Stylonychia. Eur J Protistol 34:446-457

Putt M, Stoeker DK (1989) An experimentally determined carbon:volume ratio for 'oligotrichous' ciliates from estuarine and coastal waters. Limnol Oceanogr 35:1097-1103

Editorial responsibility: Fereidoun Rassoulzadegan, Villefranche-sur-Mer, France
Riaux-Gobin C, Poulin M, Prodon R (2003) Land-fast ice microalgal and phytoplanktonic communities (Adelie Land, Antarctica) in relation to environmental factors during ice break-up. Antarct Sci 15:353-364

Rivkin RB, Legendre L (2001) Biogenic carbon cycling in the upper ocean: effects of microbial respiration. Science 291:2398-2400

Rose JM, Caron DA (2007) Does low temperature constrain the growth rates of heterotrophic protists? Evidence and implications for algal blooms in cold waters. Limnol Oceanogr 52:886-895

Safi KA, Griffiths FB, Hall JA (2007) Microzooplankton composition, biomass and grazing rates along the WOCE SR3 line between Tasmania and Antarctica. Deep-Sea Res 54:1025-1041

Saito R, Kudoh S, Sato T, Watanabe K, Fukuchi M (1998) Composition of sinking particulates collected under fast ice near Syowa Station, East Antarctica, in early spring and early summer, 1994. Nankyoku Shiryo 42: 252-268

> Sakshaug E, Bricaud A, Dandonneau Y, Falkowski PG and others (1997) Parameters of photosynthesis: definition, theory and interpretation of results. J Plankton Res 19:1637-1670

Scott FJ, Marchant HJ (2005) Antarctic marine protists. ABRS, Canberra

Scott FJ, Davidson AT, Marchant HJ (2000) Seasonal variation in plankton, submicrometer particles and size fractionated dissolved organic carbon in Antarctic coastal waters. Polar Biol 23:635-643

Sherr EB (1988) Direct use of high molecular weight polysaccharide by heterotrophic flagellates. Nature 335:348-351

Sherr EB, Sherr BF (1994) Bacterivory and herbivory: key roles of phagotrophic protists in pelagic food webs. Microb Ecol 28:223-235

Sherr EB, Sherr BF, Fessenden L (1997) Heterotrophic protists in the Central Arctic Ocean. Deep-Sea Res 44:1665-1682

Smith WO Jr, Nelson DM (1986) Importance of ice edge phytoplankton production in the Southern Ocean. Bioscience 36:347-354

Smith WO Jr, Nelson DM, Mathot S (1999) Phytoplankton growth rates in the Ross Sea, Antarctica, determined by independent methods: temporal variations. J Plankton Res 21:1519-1536

Strom SL, Benner R, Ziegler S, Dagg MJ (1997) Planktonic grazers are a potential source of marine dissolved organic carbon. Limnol Oceanogr 42:1364-1374

Taylor GT, Haberstroh PR (1988) Microzooplankton grazing and planktonic production in the Bransfield Strait observed during the RACER program. Antarct $J$ US 23:126-128

Tsuda A, Kawaguchi S (1997) Microzooplankton grazing in the surface water of the Southern Ocean during an austral summer. Polar Biol 18:240-245

Zapata M, Rodríguez F, Garrido JL (2000) Separation of chlorophylls and carotenoids from marine phytoplankton: a new HPLC method using reversed phase $\mathrm{C}_{8}$ column and pyridine-containing mobile phases. Mar Ecol Prog Ser 195:29-45

Submitted: March 16, 2007; Accepted: September 10, 2007 Proofs received from author(s): December 15, 2007 